\title{
Determinants of book reading and library attendance in Colombia. A microeconometric approach
}

\author{
Maria Luisa Palma ${ }^{1 *} \cdot{\text { Luis F. } \text { Aguado }^{2} \cdot \text { Ana María Osorio }}^{2}$ \\ ${ }^{1}$ Department of Economics and Economic History, University of Seville, Spain \\ ${ }^{2}$ Department of Economics, Pontificia Universidad Javeriana, Seccional Cali, Colombia
}

Received: 17 March 2014

Revised: 1 July 2014

Accepted: 9 July 2014

\begin{abstract}
The article explores the determinants of the decision to read books and visit libraries in a developing country, Colombia, based on data from the Encuesta de Consumo Cultural 2008 [Cultural Consumption Survey] (ECC2008). For this purpose, multilevel logistic regressions are estimated, results showing that a high level of education and a greater socioeconomic status have a positive and significant effect on the decision to read, whereas socioeconomic status does not prove significant vis-à-vis library visits. Moreover, the VPC (Variance Partition Coefficient), $5.33 \%(6.58 \%)$ of the residual variation in the propensity to read at least one book (visit a library), can be attributed to unobserved features of the neighbourhood.
\end{abstract}

Keywords: cultural participation, reading habits, library attendance, multilevel logistic models, Colombia

JEL Classification Codes: Z11, D12, C25

\section{Introduction}

Exploring the determinants behind book reading and library attendance constitutes an interesting case study, firstly because these activities are perhaps the most basic means of engaging in culture (Fernández-Blanco and Prieto-Rodríguez, 2009), and secondly because they have received little attention from the viewpoint of participation determinants (Amez, 2010; Gray, 2003).

The available empirical literature addressing the topic in the field of cultural economics remains scarce and has mainly focused on the use of temporal series to estimate demand elasticities for books (Billintmayer, 1992; Hjorth-Andersen, 2000; Prieto-Rodríguez et al., 2005; Ringstand and Loyland, 2006; Palma et al., 2009) or, in the case of Spain, on participation studies analysing the purchase of books and periodicals, such as the works conducted by Escardíbul and Villarroya (2009) and Villarroya and Escardíbul (2010) or on exploring the factors influencing the decision to read and reading frequency Fernández-

\footnotetext{
* Corresponding author. E-mail: mpalma@us.es.

Citation: Palma, M.L., Aguado, L.F. and Osorio, A.M. (2014) Determinants of book reading and library attendance in Colombia. A microeconometric approach, Economics and Business Letters, 3(2), 79-86.
} 
Blanco and Prieto-Rodríguez (2009), a work which ties in more closely with the present study. The literature remains even scarcer in the case of developing countries, prominent studies including those by Parra and Corzo (2008) analysing the impact of the National Reading and Libraries Plan on the number of books read in Colombia, or Muñoz- Cáceres (2012) into reading behaviour in Chile, in addition to the descriptive studies into reader behaviour and reading habits published by CERLAC (2012), or Gamboa and Reina (2006) for the Colombian Book Chamber.

The main aim of the present article is to explore the determinants of the decision to read books or attend libraries in Colombia based on data from the 2008 Cultural Consumption Survey (hereinafter ECC2008). Given the dichotomous nature of the variables of interest and the hierarchical structure of the ECC2008, multilevel logistic regressions are estimated to capture the effect of the various neighbourhoods on the two decisions. The neighbourhood may influence residents in a number of ways, such as through the social interactions generated therein, the geographical location, as well as access to services and opportunities (Galster, 2012).

The principal hypothesis to be tested is that despite being a developing country which has a low reading rate and a high income imbalance, the factors influencing the decision to read and attend libraries do not differ substantially from those found in developed countries.

The paper contributes to the empirical literature addressing cultural participation in two ways: firstly by providing an analysis of the decision to read and attend libraries, thus far absent from studies into developing countries, as is the case of Colombia, and secondly due to the use of multilevel models to capture the effect which individuals' environment (neighbourhood) has on the decision to read and visit libraries.

The findings to emerge from the models estimated are useful for implementing cultural policies aimed at boosting citizens' reading rates and access to libraries within the framework of the National Reading and Libraries Plan (2003-2010). The article is organised in sections. Section two presents the ECC2008 and the estimation methods. Section three discusses the findings, while the final section presents the main conclusions.

\section{Data and methods}

The ECC2008 provides a description of the cultural activities and behaviour of persons over the age of five in Colombia. The sample is representative at a national scale, employs a threestage probabilistic sample design stratified at the first stage, and covers 37,381 individuals who live in the municipal capitals of 68 municipalities. In order to reflect the role of context, the sample was restricted to those over the age of 11 who lived in the country's four main cities (Bogota D.C, Medellin, Cali, and Barranquilla) ${ }^{1}$, and who, in the week prior to when the study was carried out, were engaged in their usual activities. Moreover, in the case of book reading, only those who stated they read for pleasure were included, which reduced the sample to 8,660 individuals.

The "sector" variable was used as a proxy of the neighbourhood, in other words the nearest context to which individuals are exposed and which might affect their decision to read or go to a library. The sample included 171 sectors (hereinafter referred to as neighbourhoods). In line with the ECC2008, a sector is generally equal to a neighbourhood comprising between one and nine sections, made up of approximately 20 adjacent blocks belonging to the same sector (DANE 2008).

\footnotetext{
${ }^{1}$ Information from the 2005 National Population Census indicates that the four cities represent $38.4 \%$ of the country's population located in municipal capitals. In addition, the GDP generated in the respective metropolitan areas accounts for $52.4 \%$ of domestic GDP (DANE 2013).
} 
Table 1. Definition of variables

\begin{tabular}{|c|c|c|c|}
\hline Variable & Description & & Typology \\
\hline \multicolumn{4}{|c|}{ Dependent variables [ $P_{i}^{t}$ ] } \\
\hline Book reading & $\begin{array}{l}\text { Have you read books over the last twelve } \\
\text { months? }\end{array}$ & $D$ & $1=$ yes $; 0=$ No \\
\hline $\begin{array}{l}\text { Library } \\
\text { attendance }\end{array}$ & $\begin{array}{l}\text { Have you been to a library over the last twelve } \\
\text { months? }\end{array}$ & $D$ & $1=$ yes $; 0=$ No \\
\hline \multicolumn{4}{|c|}{ Explanatory variables $\left[x_{i}\right]$} \\
\hline \multicolumn{4}{|c|}{ Personal features $\left[N_{i}\right]$} \\
\hline age & Age in years & $C$ & Number of years \\
\hline age2 & Age squared & $C$ & Number of years \\
\hline men & Male & $D$ & $1=$ Male $; 0=$ Female \\
\hline \multicolumn{4}{|c|}{ 'Mixed variables $\left[M_{i}\right]$} \\
\hline single & Single & $D$ & $1=$ yes $; 0=$ No \\
\hline married & Married/civil partnership & $D$ & $1=$ yes; $0=\mathrm{No}$ \\
\hline wid-div & Widowed+divorced & $D$ & $1=$ yes $; 0=$ No \\
\hline afdes & Describe themselves as being of African descent & $D$ & $1=$ yes $; 0=$ No \\
\hline \multicolumn{4}{|c|}{ Accumulated cultural capital [ $\left.C_{i}\right]$} \\
\hline educlev & $\begin{array}{l}\text { Level of education. Dichotomised in the final } \\
\text { analysis }\end{array}$ & $O$ & $\begin{array}{l}1=(\text { None }) ; 2=(\text { Pre-school-Basic }) ; 3= \\
\text { (Secondary) } ; 4=(\text { Technical-Technological }) ; 5= \\
\text { (University }+ \text { Postgraduate })\end{array}$ \\
\hline $\begin{array}{l}\text { Passive cultural } \\
\text { participation }\end{array}$ & $\begin{array}{l}\text { Have you taken part in cultural activity courses or } \\
\text { workshops? }\end{array}$ & $D$ & $1=$ yes $; 0=\mathrm{No}$ \\
\hline \multicolumn{4}{|c|}{ socioeconomic status $\left[S_{i}\right]$} \\
\hline ses & $\begin{array}{l}\text { Socio-economic status } / 1 \text {. Dichotomised in the } \\
\text { final analysis }\end{array}$ & $O$ & $1=($ Low $) ; 2=($ Middle $) ; 3=($ High $)$ \\
\hline \multicolumn{4}{|c|}{ Time restrictions $\left[T_{i}\right]$} \\
\hline leisuremf & $\begin{array}{l}\text { Hours available for free-time activities from } \\
\text { Monday to Friday. }\end{array}$ & $C$ & Number of hours \\
\hline leisuress & $\begin{array}{l}\text { Hours available for free-time activities from } \\
\text { Saturday to Sunday. }\end{array}$ & $C$ & Number of hours \\
\hline child5 & Children under five in the household & $D$ & $1=$ yes $; 0=$ No \\
\hline \multicolumn{4}{|l|}{ Others $\left[R_{i}\right]$} \\
\hline place & $\begin{array}{l}\text { Place where the survey was conducted (Bogota; } \\
\text { Medellin, Cali, Barranquilla) }\end{array}$ & $D$ & $1=$ Yes $; 0=$ No \\
\hline
\end{tabular}

/1. In this case, socioeconomic level or status is measured through a proxy variable of wealth. In Colombia, the socioeconomic stratification of dwellings is used as a basis for the levying of certain taxes or fees charged for certain public services provided for those dwellings. This is based on a series of parameters related to the physical features of the dwelling and the place or neighbourhood where it is located. Dwellings are classified into six groups; group 1 corresponding to the lowest level, and group 6 to the highest. For the purposes of estimating the models, these have been divided into three groups: groups 1 and 2 are the lowest level; groups 2 and 3 are the middle level, and groups 5 and 6 are the highest level.

Multilevel models allow us to take account of the hierarchical structure of the data and explore inter- and intra-group variations (Steele, 2008) in addition to analysing variables at various levels simultaneously (Hox, 2010). The article estimates two-level logistic regression 
models, with 8,660 individuals in 171 neighbourhoods, adopting the following general specification:

$$
\log \left(\pi_{i j}\right)=\log \left[\frac{\pi_{i j}}{1-\pi_{i j}}\right]=\beta_{0}+\beta_{i j} X_{i j}+\mu_{j}
$$

where $\pi_{i j}$ is the probability that the event will occur (in this case reading a book or visiting a library), $X_{i, j}$ is a vector of explanatory variables at an individual level (see Table 1 ), $\beta_{0}$ and $\beta_{1}$ are the commonly estimated regression coefficients, and $u_{j}$ are the neighbourhood level residuals, assumed to be distributed normally with a mean of zero and variance $\sigma_{u}^{2}$.

\section{Results}

Table 2 shows that the main reason stated by individuals for not reading a book or visiting a library over the previous twelve months was lack of interest, $63.6 \%$ and $60.5 \%$ respectively, a reason that was twice as common as lack of time (34.5\% and $29.2 \%)$. The first motive might be linked to individuals' preferences, since their cultural capital consumption might be focused on other cultural activities. The second reason might be related to socioeconomic determinants, in this instance the twin barrier they face in terms of time and money.

Table 2. Reasons for not reading and not attending libraries

\begin{tabular}{lcc}
\hline \hline & \multicolumn{2}{c}{ Reasons for which subjects did not: } \\
\cline { 2 - 3 } & read books & attend libraries \\
\hline \hline Lack of time & $34.5 \%$ & $29.2 \%$ \\
Lack of interest/don't like it & $63.6 \%$ & $60.5 \%$ \\
Library too far away & $1.4 \%$ & $11.0 \%$ \\
Lack of money & $5.6 \%$ & $7.9 \%$ \\
\hline \hline
\end{tabular}

Table 3 displays the profile of non-book readers and non-visitors to libraries. These tend to be married people averaging 41 years of age, with a level of educational attainment below secondary and who are from a low socioeconomic status. There are also significant differences between those who read and those who do not (go to libraries and do not) in most of the sociodemographic variables analysed. 
Table 3. Profiles of readers and library visitors

\begin{tabular}{|c|c|c|c|c|c|c|}
\hline & \multicolumn{3}{|c|}{ Book reading } & \multicolumn{3}{|c|}{ Library attendance } \\
\hline & $\begin{array}{c}\text { Readers } \\
(\mathrm{N}=4033)\end{array}$ & $\begin{array}{c}\text { Non-readers } \\
(\mathrm{N}=4627)\end{array}$ & $\begin{array}{c}\text { Mean } \\
\text { differences } \\
\text { test }\end{array}$ & $\begin{array}{c}\text { Library } \\
\text { attendance } \\
(\mathrm{N}=1741)\end{array}$ & $\begin{array}{c}\text { Non- } \\
\text { attendance } \\
\text { at libraries } \\
(\mathrm{N}=6919)\end{array}$ & $\begin{array}{c}\text { Mean } \\
\text { differences } \\
\text { test }\end{array}$ \\
\hline Age (years) & 37.90 & 40.97 & $* * *$ & 30.01 & 41.94 & $* * *$ \\
\hline Male & 0.42 & 0.48 & $* * *$ & 0.42 & 0.46 & $* *$ \\
\hline \multicolumn{7}{|l|}{ Marital status } \\
\hline Single & 0.41 & 0.30 & $* * *$ & 0.63 & 0.28 & $* * *$ \\
\hline Married/Civil partnership & 0.46 & 0.57 & $* * *$ & 0.31 & 0.57 & $* * *$ \\
\hline Separated/Widowed & 0.12 & 0.13 & $* * *$ & 0.06 & 0.14 & $* * *$ \\
\hline \multicolumn{7}{|l|}{ Educational attainment } \\
\hline None & 0.00 & 0.01 & $* * *$ & 0.00 & 0.01 & $* * *$ \\
\hline Primary/Basic & 0.14 & 0.33 & $* * *$ & 0.11 & 0.28 & $* * *$ \\
\hline Secondary & 0.44 & 0.51 & $* * *$ & 0.41 & 0.49 & $* * *$ \\
\hline Technical & 0.14 & 0.08 & $* * *$ & 0.12 & 0.10 & $* * *$ \\
\hline University/Postgraduate & 0.28 & 0.07 & $* * *$ & 0.36 & 0.12 & $* * *$ \\
\hline \multicolumn{7}{|l|}{ Socioeconomic status } \\
\hline Low & 0.39 & 0.55 & $* * *$ & 0.41 & 0.49 & $* * *$ \\
\hline Middle & 0.52 & 0.42 & $* *$ & 0.49 & 0.46 & $* * *$ \\
\hline High & 0.09 & 0.03 & $* * *$ & 0.09 & 0.05 & $* * *$ \\
\hline City of residence & 0.55 & & & & & \\
\hline Bogota & 0.18 & 0.53 & $* * *$ & 0.59 & 0.53 & $* * *$ \\
\hline Medellin & 0.16 & 0.16 & & 0.24 & 0.16 & $* * *$ \\
\hline Cali & 0.11 & 0.21 & $* * *$ & 0.09 & 0.21 & $* * *$ \\
\hline Barranquilla & 0.11 & 0.10 & & 0.08 & 0.11 & $* * *$ \\
\hline
\end{tabular}

Table 4 shows the estimation results of the two multilevel logistic models for the determinants of book reading (model 1) and library attendance (model 2). Broadly speaking, the results agree with those obtained in other previous studies for Colombia (Parra and Corzo, 2008) and Spain (Fernández-Blanco and Prieto-Rodríguez, 2009). The odds ratio for age and age squared indicate that the younger the individuals are, the less likely they are to read or attend libraries. However, after a certain age, individuals are equally likely to read or attend libraries or not. Males are approximately $24 \%$ less likely to read books (attend libraries) than females. As regards marital status, those who are married are less likely (23.5\%) to read compared to those who are single. As regards attending libraries, in addition to being married, being separated or widowed also reduces the likelihood of going compared to being single.

Having completed post-secondary level education increases both the propensity to read and to go to libraries. By way of an example, compared to those who have no qualifications, those who have a university degree are 11.13 times more likely to read books and 28.27 times more likely to visit libraries. Passive cultural participation positively affects the probability of reading books and going to libraries. In contrast, socioeconomic status only seems to affect the propensity to read books. Individuals from middle and high levels are approximately 1.3 and 1.8 times more likely, respectively, to read books than those from the lowest level. In addition, declaring oneself to be of afro-descendant origin only affects visits to libraries. 
Available leisure time at weekends has a limited impact on the two activities, whereas the presence of children under the age of five in the household reduces the probability of reading books by $20 \%$, and attending libraries by $36 \%$. Finally, living in Cali reduces the propensity to read books by almost $19 \%$ compared to living in Bogota. Compared to Bogota, the propensity to visit libraries is greater in Medellin (1.5 times greater) and less in Cali and Barranquilla (53\% and $45 \%$ less likely, respectively). As regards the contextual effect, in terms of VPC, $5.33 \%$ (6.58\%) of the residual variation in the propensity to read at least one book (visit a library) can be attributed to unobserved features of the neighbourhood.

The findings to emerge from the multilevel models suggest that in addition to the influence of individual and family traits, there are key neighbourhood related factors which can influence book reading and library visiting habits. The neighbourhood might have a bearing on individuals' behaviour, either through geographical location or the social interactions generated therein. Finally, the lower propensity to go to libraries amongst individuals who declare themselves to be afro-descendant might reflect the influence of the poorer environment in which they live in Colombia (Vivas, 2011). This bears out the importance of libraries as a key cultural facility in the community, since visits thereto are not linked to socioeconomic status, and it thus provides evidence of the need for public investment programmes in libraries in the National Reading and Libraries Plan (PNLB).

\section{Concluding Remarks}

The article provides empirical evidence, thus far absent, concerning the determinants driving the decision to read books and attend libraries for a developing country, Colombia, using multilevel models to capture the effect which individuals' context has on such decisions. The paper offers similar results to those obtained for Spain by Fernández-Blanco and PrietoRodríguez (2009). The results to emerge from the models estimated provide insights into the need to implement cultural policies aimed at boosting reading rates and access to libraries, and underpin the importance of increasing the population's levels of education, particularly at secondary and university level. The findings also reveal the importance of the context [neighbourhood] as an aspect to be considered when devising programmes aimed at encouraging individuals to engage in the two cultural activities studied. In this vein, policies which promote access to cultural facilities such as libraries, together with educational programmes such as promoting reading clubs outside of schools (at bus-stops, on buses, in markets, in recreational areas, etc), that stimulate interest and reading habits, might prove significant.

Acknowledgements. We would like to thank participants in the $\mathrm{V}$ Workshop on Cultural Economics and Management, October $24^{\text {th }}-25^{\text {th }} 2013$, University of Cádiz (Spain) for their useful comments. 
Table 4. Determinants of book reading and library attendance

\begin{tabular}{|c|c|c|c|c|}
\hline \multirow{4}{*}{ Dependent variable } & \multicolumn{4}{|c|}{ MultilevelLogit } \\
\hline & \multicolumn{2}{|c|}{ Model 1} & \multicolumn{2}{|c|}{ Model 2} \\
\hline & \multicolumn{2}{|c|}{ Book reading } & \multicolumn{2}{|c|}{ Attendinglibraries } \\
\hline & OR & $\mathrm{CI}$ & OR & $\mathrm{CI}$ \\
\hline Age (year) & $0.976 * * *$ & {$[0.96,0.99]$} & $0.860 * * *$ & {$[0.84,0.88]$} \\
\hline $\operatorname{Age}^{\wedge} 2$ & $1.000 * *$ & {$[1.00,1.00]$} & $1.001 * * *$ & {$[1.00,1.00]$} \\
\hline Male & $0.761 * * *$ & {$[0.69,0.84]$} & $0.765 * * *$ & {$[0.67,0.87]$} \\
\hline Marital status (ref: single) & . & & . & \\
\hline Married/Civil partnership & $0.765 * * *$ & {$[0.67,0.87]$} & $0.659 * * *$ & {$[0.56,0.78]$} \\
\hline Separated/Widowed & 0.916 & {$[0.76,1.10]$} & $0.693 * *$ & {$[0.53,0.91]$} \\
\hline afdes & 0.977 & {$[0.78,1.22]$} & $0.667 * *$ & {$[0.46,0.96]$} \\
\hline Educationalattainment (ref: none) & . & & . & \\
\hline Pre-school/Basic & 1,512 & {$[0.73,3.14]$} & 3,758 & {$[0.49,28.55]$} \\
\hline Secondary & $2.833^{* *}$ & {$[1.36,5.90]$} & $6.213^{*}$ & {$[0.82,47.11]$} \\
\hline Technical & $5.349 * * *$ & {$[2.54,11.27]$} & $10.23 * *$ & {$[1.34,78.06]$} \\
\hline University/Postgraduate & $11.13 * * *$ & {$[5.27,23.49]$} & $28.27 * *$ & {$[3.71,215.35]$} \\
\hline Passive cultural participation & $2.210 * * *$ & {$[1.94,2.52]$} & $3.103 * * *$ & {$[2.69,3.59]$} \\
\hline Socioeconomic status (ref: low) & . & & . & \\
\hline Middle & $1.287 * * *$ & {$[1.11,1.50]$} & 1,116 & {$[0.92,1.36]$} \\
\hline High & $1.818 * * *$ & {$[1.29,2.56]$} & 0.883 & {$[0.60,1.31]$} \\
\hline Leisurehours (Monday-Friday) & $1.007 * *$ & {$[1.00,1.01]$} & $1.013 * * *$ & {$[1.01,1.02]$} \\
\hline Leisurehours (Saturday-Sunday) & 0.994 & {$[0.98,1.00]$} & 0.998 & {$[0.99,1.01]$} \\
\hline Children $<5$ years of age in the household & $0.804 * * *$ & {$[0.71,0.90]$} & $0.637 * * *$ & {$[0.54,0.75]$} \\
\hline City of residence (ref: Bogota D.C) & . & & . & \\
\hline Medellin & 1,039 & {$[0.82,1.32]$} & $1.524 * *$ & {$[1.16,2.00]$} \\
\hline Cali & $0.813^{*}$ & {$[0.65,1.01]$} & $0.465 * * *$ & {$[0.35,0.62]$} \\
\hline Barranquilla & 0.98 & {$[0.73,1.32]$} & $0.550 * *$ & {$[0.38,0.80]$} \\
\hline $\mathrm{N}$ & 8660 & & 8660 & \\
\hline Log likelihood & -5204.11 & & -3227.28 & \\
\hline \multicolumn{5}{|l|}{ Prob $>$ chi $2=0.0000$} \\
\hline Wald chi2(19) & 958.98 & & 1391.57 & \\
\hline Neighbourhoodvariance & $0.1858 * * *$ & & $0.232 * * *$ & \\
\hline VPC (VariancePartitionCoefficient) & $5.33 \%$ & & $6.58 \%$ & \\
\hline
\end{tabular}

OR: Odds Ratio, CI: 95\% confidence intervals in square brackets

$* \mathrm{p}<0.1, * *_{\mathrm{p}}<0.05, * * *_{\mathrm{p}}<0.001$

VPC: Proportion of total variance due to differences between neighbourhoods

Nullmodelreading (VPC $=13.5 \%$ )

Nullmodellibraries (VPC $=12.8 \%)$

\section{References}

Amez, L. (2010) Mapping the field of arts and Economics. Paper 16th International Conference on Cultural Economics, ACEI, Copenhagen. 
Bittllingmayer, G. (1992) The elasticity of the demand for books, resale maintenance and the Lerner index, Journal of Institutional and Theoretical Economics, 148 (4), 588-606.

CERLAC (2012) El libro en cifras. Boletín Estadístico del libro en Iberoamérica. Bogota: CERLAC-UNESCO from http://www.cerlalc.org/files/tabinterno/7ad328_Libro_Cifras_Ago2012.pdf. Accessed 12 september 2013.

DANE (2008) Encuesta de Consumo Cultural 2008, Manual de Diligenciamiento y Conceptos Básicos. Departamento Administrativo Nacional de Estadística (DANE). Bogotá: DANE.

DANE (2013) Cuentas Departamentales, Base 2005. Años 2010-2011 provisional. Departamento Administrativo Nacional de Estadística (DANE). Bogotá: DANE.

Escardíbul, O; and Villarroya, A. (2009) Who buys newspaper in Spain? An analysis of the determinants of the probability to buy newspapers and the amount spent, International Journal of Consumer, 33, 64-71.

Fernández-Blanco, V. and Prieto-Rodríguez, J. (2009) Análisis de los hábitos de lectura como una decisión económica, Estudios de Economía Aplicada, 27 (1), 87-110.

Galster, G.C. (2012) The mechanism(s) of neighbourhood effects: theory, evidence, and policy implications, in M. van Ham, D. Manley, N. Bailey, L. Simpson and D. Mclennan (eds.): Neighbourhood effects research: new perspectives, New York: Springer, 23-56.

Gamboa, C. and Reina, M. (2006) Hábitos de lectura y consumo de libros en Colombia. Fundación para la Educación Superior y el Desarrollo. Bogotá: Fedesarrollo.

Gray, C. (2003) Participation, in Towse, R. (ed.): A Handbook of Cultural Economics, Cheltenham: Edward Elgar, 356-365.

Hjorth-Andersen, C. (2000) A model of the Danish book market, Journal of Cultural Economics, 24(1), 27-43.

Hox, J.J. (2010) Multilevel analysis: techniques and applications, New York: Taylor \& Francis.

Muñoz-Cáceres, K. (2012) ¿Qué lectores queremos? Un análisis del comportamiento lector en Chile desde la perspectiva económica. Tesis de pregrado. Facultad de economía y Negocios Escuela de economía y administración from http://www.tesis.uchile.cl/handle/2250/112240. Accessed 12 september 2013.

Palma-Martos, M.L., Martín-Navarro, J.L. and Jaén-García, M. (2009) El mercado del libro en España 1989-2006. Un análisis económico, Estudios de Economía Aplicada, 27(1), 225-252.

Parra, J. and Corzo, O. (2008) Impacto del Plan Nacional de Lectura y Bibliotecas (PNLB), Cuadernos de Economía, 31(87), 115-132.

Prieto-Rodríguez, J., Romero-Jordán, D. and Sanz-Sanz, J.F. (2005) Is a tax cut on cultural goods consumption actually desirable? A microsimulation analysis applied to Spain, Fiscal Studies, 26(4), 549-575.

Ringstand, V. and Loyland, K. (2006) The demand for books by means of consumer survey data, Journal of Cultural Economics, 30 (2), 141-155.

Steele, F. (2008) Module 5: Introduction to multilevel modelling (Concepts) (Vol. 5), Centre for Multilevel Modelling, University of Bristol.

Vivas, H. (2011) El desarrollo en 3D: las claves de las diferencias en la calidad de vida de las regiones, Revista de Ciencias Sociales, 7, 197-224.

Villarroya, A. and Escardíbul, O. (2010) La demanda de libros y publicaciones periódicas en España, Estudios de Economía Aplicada, 28(1), 1-22. 